Received: March, 2019

Accepted: December, 2019

ISSN $2006-6996$

\title{
MICROPROPAGATION OF BANANA (Musa SPP) USING TEMPORARY IMMERSION BIOREACTOR SYSTEM
}

\author{
Abdulmalik, M.M., ${ }^{1}$ Usman, I.S., ${ }^{1}$ Nasir, A.U. ${ }^{3}$ and Sani, L.A. ${ }^{2 *}$ \\ ${ }^{1}$ Department of Plant Science, Ahmadu Bello University, Zaria, Nigeria \\ ${ }^{2}$ Department of Plant Biology, Bayero University Kano, Kano, Nigeria \\ ${ }^{3}$ National Sugar Development Council-Sugarcane Biofactory, Ahmadu Bello University, \\ Zaria, Nigeria \\ *Corresponding Authors:labdul.bot@buk.edu.ng
}

\section{ABSTRACT}

Banana is an important crop in the tropics which possess the potential for commercial production in Nigeria. Large scale production requires large volume of planting materials which may be difficult to obtain using conventional methods of propagation. Temporary immersion bioreactor system (TIBs) is a cost effective method for micropropagation of plants. The present study was carried out to develop an efficient method for rapid multiplication of banana using temporary immersion bioreactor system (TIBs). Banana microshoots were regenerated from young suckers obtained from field grown plants using conventional plant tissue culture. Microshoots of $2 \mathrm{~cm}$ length were used as explants for multiplication in temporary immersion bioreactor system. Ten (10) explants were cultured in bioreactor bottles containing Murashinge and Skoog (MS) liquid media supplemented with different concentrations of 6-bezylaminopurine (BAP) with or without 250mg/L Activated Charcoal (AC). Results showed that explants cultured in media supplemented with $2 \mathrm{mg} / \mathrm{L}$ or $1 \mathrm{mg} / \mathrm{L}$ BAP without $A C$ gave the highest shoot multiplication rate of $900 \%$ and $800 \%$, respectively compared to hormone free media. Production of competent plants (plants ready for ex vitro establisment) were however, influenced by the presence of $A C$ and the highest percentage of competent plants (80\%) were produced when media was fortified with $1 \mathrm{mg} / \mathrm{L} B A P+250 \mathrm{mg}$ AC. Regenerated plants were successfully established in the field and were morphologically normal and fertile.

Key words: Cavendish Banana, Micropropagation, TIBs, BAP, Activated Charcoal

\section{INTRODUCTION}

Banana (Musa spp.) is one of the most important cultivated tropical fruits, with world production estimated at 113.9 million metric tons (FAOSTAT, 2017). The fruit is a good source of energy, vitamins $A, B_{6}, C$, minerals and dietary fiber (Mohapatra et al., 2010). Banana is propagated by vegetative method using suckers that arises from the underground stems. This method of propagation is slow and allows for transfer of systemic diseases from generation to generation. Large scale production of banana requires large volume of planting materials, which are hardly obtained by conventional method of propagation, and as well, bulky to move. Plant tissue culture offers an opportunity for large scale production of disease-free, uniform planting materials in a short period of time. Rapid multiplication of banana using conventional tissue culture has been reported (Karule et al., 2016; Keshari and Pradhan, 2016). The use of conventional tissue culture for commercial production of banana is contrained by high cost of seedlings resulting from low multplication rate of propagules, intensive labour requirement and low survival during acclimatization. Temporary immersion bioreactor system (TIBs) is a system that results in rapid multiplication of plants by intermittent immersion in liquid nutrients media under sterile condition. The sytem is based on periodic complete immersion of the propagules by pneumatic driven transfer of liquid medium. In temporary immersion bioractor system, gelling agents are not required which in most cases are not inert components and do not allow for automation. 
Temporary immersion bioreactor system is therefore, an automated system resulting in reduced cost, rapid multiplication rate and efficient growth of the cultured plants. An automated sytem for microprogation of Cavendish Banana using temprary immersion is reported in this paper.

\section{MATERIALS AND METHODS}

The study was conducted at the National Sugar Development Council (NSDC) Sugarcane Biofactory, Institute for Agricultural Research (IAR), Ahmadu Bello University Zaria. The media used in the study was modified Murashige and Skoog (MS) medium (Murashinge and Skoog, 1962) supplemented with $3 \%$ sucrose. The $\mathrm{pH}$ of the media was adjusted to 5.8 using $0.5 \mathrm{M}$ $\mathrm{NaOH}$ and the media was autoclaved at $121^{\circ} \mathrm{C}$ for 15 minutes.Young suckers were obtained from matured field grown Banana plants and used as explants for in vitro establishment. Suckers were washed thoroughly under running tap water and trimmed to $4-5 \mathrm{~cm}$ in length, then treated with commercial fungicide (Benlate) $2 \mathrm{~g} / \mathrm{L}$ for 20 minutes and rinsed in sterile distilled water before taken to the laminar flowhood. Suckers were surface sterilized by sequential treatment for 5 minutes in $70 \%$ ethanol and 20 minutes in $2.5 \%(\mathrm{w} / \mathrm{v})$ sodium hypochlorite then rinsed three times in sterile distilled water. The sterilized suckers were peeled to $2-3 \mathrm{~cm}$ in length then cultured on establisment media consisted of semi-solid MS media suplemented with $1 \mathrm{mg} / \mathrm{L}$ BAP. Cultures were incubated under 16 hour photopheriod provided by white fluorescents lamps $\left(80 \mu \mathrm{mol}\right.$ photons $\left.\mathrm{m}^{-2} \mathrm{~s}^{-1}\right)$ for four weeks. The resulting plantlets with average length of $2 \mathrm{~cm}$ were transferred to bioreactor bottles $(950 \mathrm{ml})$ containing $250 \mathrm{ml}$ of culture media. Ten explants were cultured in each bottle and two bottles were used per treatment replicated three times in a Completely Randomised Design. The TIBs culture media consisted of MS basal medium supplemented with $1 \mathrm{mg} / \mathrm{L}$ or $2 \mathrm{mg} / \mathrm{L}$ BAP and with or without $250 \mathrm{mg} / \mathrm{L} \mathrm{AC}$. Cultures were maintained in the bioreactor room under temperatures of $25 \pm 2^{\circ} \mathrm{C}$ and 16 hours photoperiod for four weeks. Feeding cycle by immersion for 3 minutes every 4 hours was programmed using electronic timer. Data was collected after four weeks of culture on shoot number, shoot length, number of leaves per shoot, number of roots and root length. The data was subjected to analysis of variance (ANOVA) using SPSS version 23.0 and means compared using Turkey significant test.

\section{RESULTS AND DISCUSSION}

An automated rapid propagation system for banana based on the principle of temporary immersion has been achieved in this study. This micropropagation system enable a periodic immersion of the plant in the nutrient media which ensured both constant supply of nutrients and efficient earation. Although hyperhydricity has been reported in liquid cultures of many plant species (Kevers et al., 2004; Smith, 2013 ), such problem was not encountered in this study

To evaluate the effect of BAP and AC on the in vitro morphogenesis in banana, different concentrations of BAP with or without AC were compared with the hormone free medium (Table 1). The media fortified with BAP alone had the heighest multiplication rate. The multiplication rate increased by $800 \%$ and $900 \%$ in media fortified with $1 \mathrm{mg} / \mathrm{L}$ or $2 \mathrm{mg} / \mathrm{L}$ BAP respectively, compared to hormone free media. BAP increase shoot multiplication by inducing axilary buds proliferation via direct control on cell division and tissue differenciation. Shoot clusters were produced in the presences of BAP alone with banana shoots produced around a central region. These shoots were short and devoid of roots, therefore were not conpetent for ex vitro establishment. Earlier study on banana production using bioreactor (Lemos et al., 2001) showed that when BAP alone was used for shoots proliferation, a rooting cycle on hormone free media is necessary.

The combination of 6-Benzylaminopurine $(1 \mathrm{mg} / \mathrm{L}$ or $2 \mathrm{mg} / \mathrm{L}$ ) with $A C$ greatly increased both multiplication rate and number of competent plants (plants ready for ex vitro establishment). A strong interaction was observed between BAP and $A C$ in the production of competent plants. While none of the regenerated plants obtained in media fortified with BAP alone was competent, the number of competent plants significantly $(P \leq 0.05)$ increased to 300 and 120 in media fortified with $1 \mathrm{mg} / \mathrm{L} \mathrm{BAP}+\mathrm{AC}$ and $2 \mathrm{mg} / \mathrm{LBAP}+\mathrm{AC}$, respectively. The positive effect of $A C$ in the production of competent plants in microprogation of banana and other plants have earlier been reported (Dumas and Monteuuis, 1995; Gübbük and Pekmezci, 2004; Nisyawati and Kariyana, 2013; Ahmed et al., 2014). AC is used in tissue culture where phenolic secretion is a common problem. It acts by absorbing the toxic phenolic compounds which alters the $\mathrm{pH}$ of the media and block nutreint absorption by the explant. In addition to adsorption of the phenolic compounds, it also provides adsorption surfaces 
for the nutreints, a process which greatly reduce the epicacy of the exogenous hormones. This could be the possible reason for low multiplication rate in media supplemented with BAP and AC when compared with media fortified with BAP alone. In the temporary immersion system, activated charcoal adsorb BAP and alters the hornal balance in favour of root formation resulting in the increased number of competent plant.

The dynamics of root formation and BAP with and without $A C$ is shown in Figure 1 . The highest root morphogenesis was obtained in the hormone free media and media fortified with a

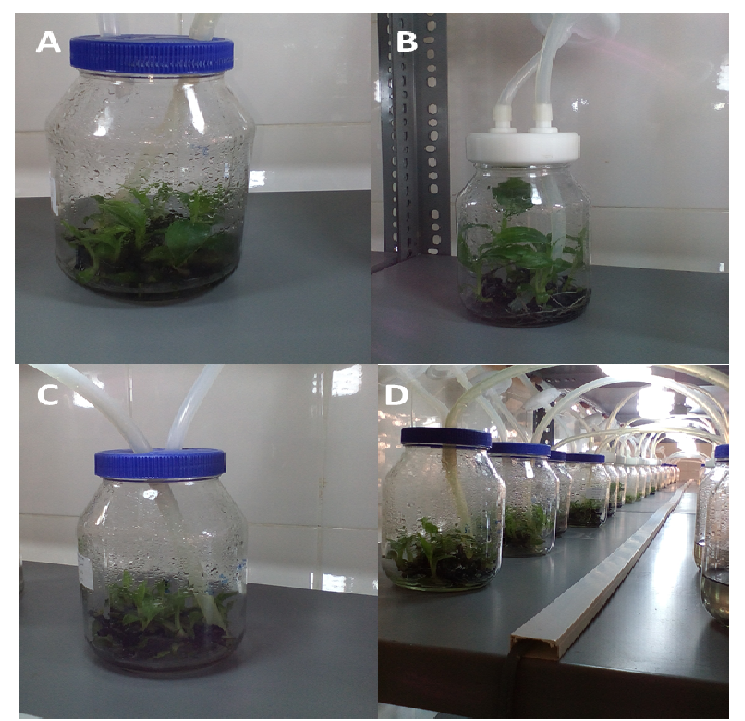

combination of BAP and AC. The presence of BAP alone in the media completely eliminates root formation. However when AC was added, significant $(P \leq 0.05)$ increase in rooting was observed and the reason could be due to hormonal inbalance in favour of rooting. There were however, no differences in the number of leaves between media fortified with BAP alone and BAP + AC. This observation may be explained by reduction in leaves developement in the temporary immersion system. The shoot clusters contained morphologically normal plants with differences only in the size, but the plants have almost equal number of leaves.

Plate 1: Micropropagation of Cavendish Banana Using Temporary Immersion Bioreactor System (TIBs). (A) multiplication on MS + 1mg BAP, (B) hormone free MS, (C) multiplication on MS + 1mg BAP without activated charcoal, (D) experimental layout

Table 1: Effect of BAP $\pm \mathrm{AC}$ on mulplication rate and number of competent plants in Banana under temporary immersion system

\begin{tabular}{|c|c|c|c|c|c|}
\hline Treatment & $\begin{array}{c}\text { Initial } \\
\text { number } \\
\text { of } \\
\text { explant }\end{array}$ & $\begin{array}{l}\text { Multiplication } \\
\text { rate }\end{array}$ & $\begin{array}{l}\text { Total } \\
\text { number of } \\
\text { Plant } \pm \text { SE }\end{array}$ & $\begin{array}{l}\text { Number of } \\
\text { competent } \\
\text { Plants } \pm \text { SE }\end{array}$ & $\begin{array}{l}\text { competent } \\
\text { plants }(\%)\end{array}$ \\
\hline Hormone Free & 60 & 1 & $60.00 \pm 2.90^{\mathrm{e}}$ & $58.00 \pm 3.07^{c}$ & 96.7 \\
\hline $\mathrm{BAP}(1 \mathrm{mg} / \mathrm{L})$ & 60 & 8 & $480.00 \pm 3.65^{b}$ & $0.00 \pm 0.00^{\mathrm{d}}$ & 0 \\
\hline $\mathrm{BAP}(2 \mathrm{mg} / \mathrm{L})$ & 60 & 9 & $540.00 \pm 5.76^{a}$ & $0.00 \pm 0.00^{d}$ & 0 \\
\hline $\mathrm{BAP}(1 \mathrm{mg} / \mathrm{L})+\mathrm{AC}$ & 60 & 6 & $360.00 \pm 2.89^{c}$ & $300.00 \pm 28.87^{\mathrm{a}}$ & 80 \\
\hline $\operatorname{BAP}(2 \mathrm{mg} / \mathrm{L})+\mathrm{AC}$ & 60 & 5 & $300.00 \pm 2.78^{d}$ & $120.00 \pm 5.77^{b}$ & 40 \\
\hline
\end{tabular}

Means with same letter along the column are not significantly different using Turkey significant test at $5 \%$ probability level. 


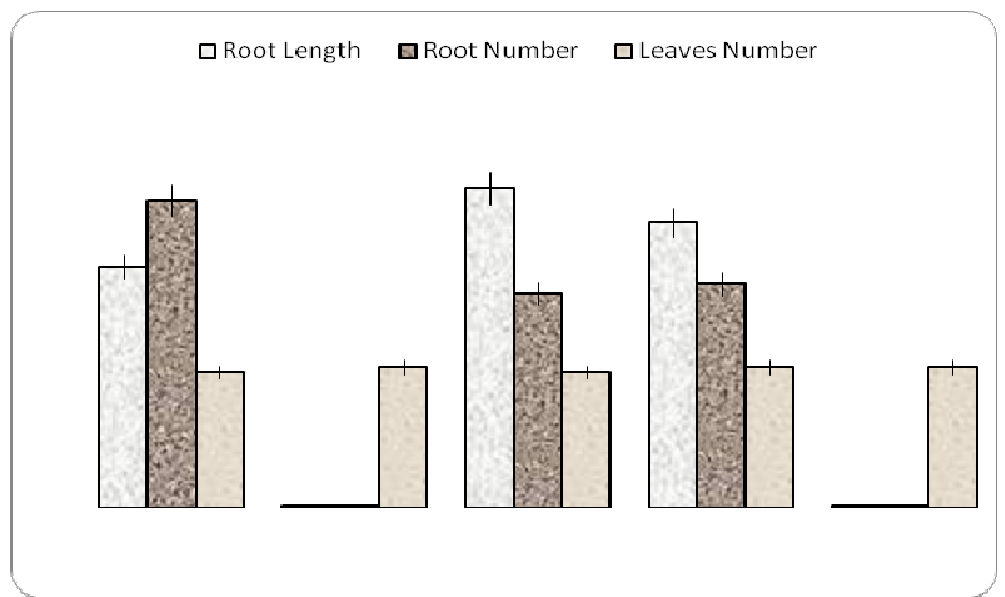

Figure: Effect of $\mathrm{BAP} \pm \mathrm{AC}$ on root morphogenesis and number of leaves in Banana under temporary immersion system.

\section{CONCLUSION}

An improved method for banana multplication using temporary immersion system has been developed to reduce the cost of micropropagated plants. The improvement achieved in this study is the elimination of rooting cycle which greatly reduced the

\section{REFERENCES}

Ahmed, S, Sharma, A., Singh, A.K., Wali, V.K. and Kumari, P. (2014). In vitro multiplication of banana (Musa sp.) cv. Grand Naine. African Journal of Biotechnology, 13(27):2696-2703.

Dumas E, Monteuuis O. (1995). In vitro rooting of micropropagated shoots from juvenile and mature Pinuspinaster explants-influence of activated charcoal. Plant Cell Tissue Organ Culture. 40:231-5.

FAOSTAT. (2017). Food and Agricultural Organization of the United Nations (FAO), FAO Statistical Database, http: //faostat.fao.org

Gübbük H. andPekmezci M. (2004). In Vitro Propagation of Some New Banana Types (Musa spp.) Turky Journal Agric and Forestry. 28: 355-36

Ikram-Ul-Haq and Dahot, M. U. (2007). Effect of permanent and temporary immersionsystems on banana micropropagation. Phakistan Journal Botany. 39(5): 1763-1772.

Karule P., Dalvi V., Kadu A., Chaudhari R., SubramaniamV. R. and Patil A. B. (2016). A commercial micropropagation protocol for virupakshi (AAB) banana via apical meristem. African Journal of Biotechnology, 15(11): 401-407

Keshari B. and Pradhan B. (2016). Effects of cytokinins and auxins on micropropagation of Musa spp. cv. Yangambi. International micropropagation time. Using this sytem it is possible to obtain 50 competent plants from 10 plantlets in 4 weeks and further extention of the production scheme to 6 months will result in the production of 156,250 competent plants ready of ex vitro establishement.

Journal of Environmental and Agriculture Research (IJOEAR) 2(5):156-158.

Kevers, C., Franck, R., Strasser, R. J., Dommes, J., and Gaspar, T. (2004). Hyperhydricity of micro-propagated shoots: A typically stressinduced change of physiological state. Plant Cell Tissue Organ Cult, 77, 181-191

Lemos, E. E. P. Ferreira, M. S. Alencar, L. M.C. Oliveira, J. and G. L. Magalhães, V. S. (2001). Micropropagation of banana terra using temporary immersion bioreactors. Revista Brasileira de Fruticultura, 23(3):482-487. http://dx.doi.org/10.1590/S010029452001000300006

Mohapatra, D., Mishra, S. and Sutar, N. (2010). Banana and its by-product utilization: an overwiew. Journal of Scientific and Industrial Research, 69: 323-329.

Murashige, T. and Skoog, F. (1962). A revised medium for rapid growth and bioassays with tobacco tissue cultures. Plant Physiology. 15:473-497.

Nisyawati and Kusuma Kariyana (2013). Effect of ascorbic acid, activated charcoal and light duration on shoot regeneration of banana cultivar barangan (Musa acuminataL.) in vitro culture. IJRRAS. 15 (1).

Smith, R. H. (2013). In Vitro Propagation for Commercial Production of Ornamentals. Plant Tissue Culture, 127-145. doi:10.1016/b978-0-12-415920-4.00012-8 